\title{
Journal of Hebrew Scriptures
}

Volume 20, Article 8

DOI: $10.5508 /$ jhs 29569

\section{The Sacredness of Firstling Animals: Evolving Perspectives within Deuteronomy}

\section{KEVIN MATTISON}




\title{
THE SACREDNESS OF FIRSTLING ANIMALS: Evolving Perspectives WITHIN DEUTERONOMY
}

\author{
KEVIN MATTISON \\ High POINT UNIVERSITY
}

\section{Introduction: Evolving Perspectives AND COMPOSITION $^{1}$}

The presence of multiple perspectives within a text that is formally or canonically unified betray that text's composite origin. Within the Pentateuch, we find significant points of disagreement between Deuteronomic, Priestly, and other texts regarding Israel's national origins and foundational laws. Conflicts and developments can be detected even within each of these pentateuchal strands. These allow us to retrace the compositional steps that might have produced the Pentateuch as we know it - even if every scholar seems to follow their own idiosyncratic path.

In this study, I examine regulations within the book of Deuteronomy concerning firstborn animals, or firstlings, that exhibit different perspectives. Three laws in the book of Deuteronomy contain commands and allowances relating to firstlings: the law of cultic place and sacrifice (Deut 12:1-28: see vv. 17-18), the tithe law (14:22-29: see vv. 23-26), and a law devoted specifically to firstlings (15:19-23: see especially vv. 19-20). The tensions among these regulations point to multiple authors. Each of these authors found a different way of reconciling two competing goals: to preserve the sacredness of firstlings and to address the problem of distance to

\footnotetext{
${ }^{1}$ Preliminary versions of this essay were presented at the 2016 Society of Biblical Literature annual meeting in San Antonio, TX and at the University of Wisconsin-Madison. I am grateful to those who responded to my oral presentations. I thank Jeremy Hutton and Chance McMahon for providing detailed comments on several drafts of this paper. This paper also benefited from extensive discussions of the topic with Jeffrey Stackert. I am grateful also to Anna Angelini and the anonymous JHS reviewers, whose guidance, comments, and suggestions led to many significant improvements.
} 
Deuteronomy's single cult site. The present study builds on my previous research on legal revision in Deuteronomy, and complements that research in several ways. For example, my previous work emphasized and perhaps overstated the degree of tension within these laws in Deuteronomy. In the present study, I characterize the various legal perspectives evident within Deuteronomy as reflecting "development" and "evolution," and at times "tension," but not "conflict" or "contradiction." Although my focus remains on relative dating and dependence among various laws, I have added a discussion of absolute dating. This addition acknowledges that literary works such as Deuteronomy were not written in an ahistorical vacuum but served real functions for real historical communities, and that the value of textual dissection lies ultimately in its ability to give us glimpses, however remote, into those ancient communities.

My comparison of Deuteronomy's firstling regulations starts with a sequential synchronic reading to introduce the texts and illustrate their varied perspectives. I turn next to the history of interpretation of these passages. The tendency of readers to resort to harmonization affirms that tension inheres in the texts themselves and not only in the imaginations of historical-critical scholars. Thus, diachronic analysis of these texts is merited and likely to be fruitful. Moreover, the history of interpretation can guide diachronic analysis in a promising direction. Next, I reconstruct the diachronic process of amendment that produced these regulations. ${ }^{2}$ I conclude by suggesting some ways in which this process of amendment can enhance our understanding of Deuteronomy's internal development, Deuteronomy's place within the legal hermeneutics of the Pentateuch, and possibilities for tying these developments (however tentatively) to historical contexts.

\section{DEUTERONOMY'S FIRSTLING REGULATIONS IN SynCHRONIC PERSPECTIVE}

The opening law of Deuteronomy (Deut 12:1-28) establishes the limitation of sacrificial worship to a single, divinely-chosen site (vv. 4-7, 10-12, 14, 17-18, 26-27). Centralization of worship creates a problem: some Israelites would have lived far from the single cult site, making travel there difficult (see v. 21). To address this problem of distance, Deuteronomy permits the non-sacrificial slaughter and consumption of livestock throughout the land (vv. 15-16, 20-25). But some offerings, and the accompanying meals, could not be severed from their cultic contexts. Deuteronomy 12:17-18 explicitly excludes some offerings, including firstlings, from local slaughter and consumption, demanding instead that they be consumed in a cultic meal at YHWH's chosen site:

\footnotetext{
${ }^{2}$ Compare, for example, Bernard Levinson's analysis of Deut 17:2-7 as a revision of Deut 13:7-12 (Deuteronomy and the Hermeneutics of Legal Innovation [New York: Oxford University Press, 1997], 118-27).
} 


\section{7 לא תוכל לאכל בשעריך מעשר דגנך ותירשך ויצהרך ובכרת

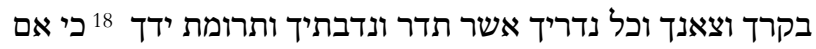

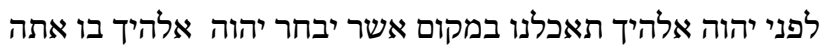

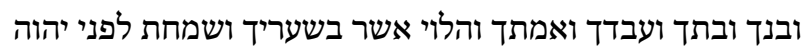

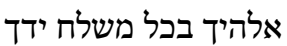

\footnotetext{
${ }^{17}$ You cannot eat locally the tithe of your grain, your wine, and your oil, or the firstlings of your herd and your flock, or any of your votive offerings that you vow, or your freewill offerings, or the contribution of your hand. ${ }^{18}$ Instead, you shall eat the aforementioned before YHWH your God, in the place that YHWH your God will choose-you, your son, your daughter, your male slave, your female slave, and the local Levite-and you shall rejoice before YHWH your God in all your undertakings. ${ }^{3}$
}

Firstlings are next mentioned in the context of Deuteronomy's "tithe law" (Deut 14:22-29). Deuteronomy 14:23 reiterates the command of Deut 12:17-18 to consume firstlings (and tithes) in a cultic meal at God's chosen site, echoing significant portions of Deut 12:17-18 in reverse order: ${ }^{4}$

3 All translations are my own. בשעריד (literally "in your gates") in vv. 17 and 18 are examples of Deuteronomy's frequent synechochic use of "gates" to refer to Israelite settlements (cf. Deut 5:14; 12:12, 15, 21; 14:21, 27, 28, 29; 15:7, 22; 16:5, 11, 14, 18; 17:2 , 8; 18:6; 23:17; 24:14; 26:12; 28:52 $[2 \mathrm{x}], 55,57 ; 31: 12)$. This usage is rare outside of Deuteronomy (Exod 20:10;

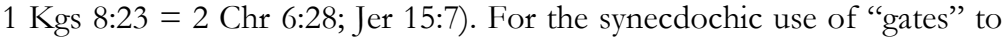
refer to localities see Ludwig Köhler and Walter Baumgartner, "שער I," in

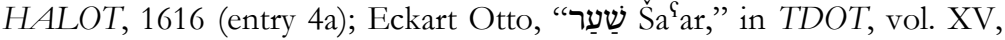
359-405, 373. Typically, but not always, Deuteronomy uses this term in שעריד opposition to the one chosen cult site. For Deuteronomy's usage of "your gates" in opposition to the central cult site, see Levinson, Deuteronomy

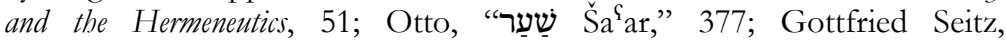
Redaktionsgeschichtliche Studien zum Deuteronomium (BWANT, 93; Stuttgart: Kohlhammer, 1971), 192. Otto suggests that Deuteronomy uses the term שער in the context of non-cultic slaughter to emphasize the secular character of the localities where such slaughter is to take place (Deuteronomium 12-34: Erster Teilband 12,1-23,15 [HThKAT, 4b; Freiburg: Herder, 2016], 1184).

4 On Deuteronomy's use of inverted citations in accordance with "Seidel's law," see Levinson, Deuteronomy and the Hermeneutics, 18-20. 


\section{Deuteronomy 12:17-18}

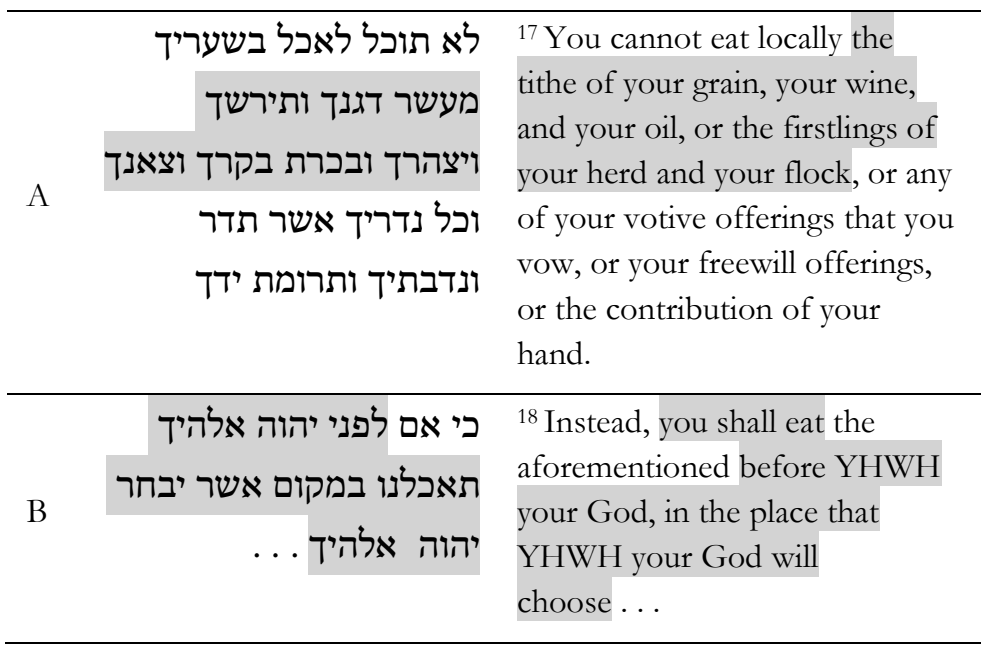

\section{Deuteronomy 14:23}

\begin{tabular}{|c|c|c|}
\hline $\mathrm{B}^{\prime}$ & 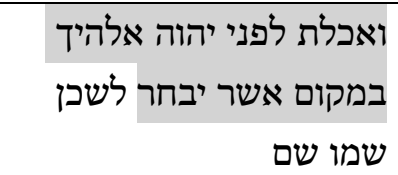 & $\begin{array}{l}\text { And you shall eat before YHWH } \\
\text { your God, in the place where he } \\
\text { will choose to establish his name }\end{array}$ \\
\hline $\mathrm{A}^{\prime}$ & מעשר דגנך תירשך ויצהרך ובכרת בקרך וצאנך & $\begin{array}{l}\text { the tithe of your grain, your } \\
\text { wine, and your oil, and the } \\
\text { firstlings of your herd and your } \\
\text { flock... }\end{array}$ \\
\hline
\end{tabular}

After this resumption of Deut 12:17-18 and a motive clause (23b), Deut 14:24-26 introduce a concession:

$$
\begin{aligned}
& \text { 24 וכי ירבה ממך הדרך כי לא תוכל שאתו כי ירחק ממך המקום }
\end{aligned}
$$

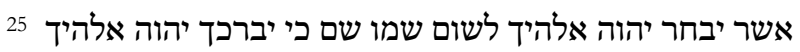

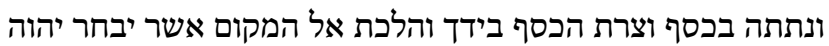

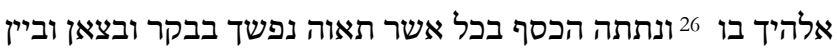

$$
\begin{aligned}
& \text { ובשכר ובכל אשר תשאלך נפשך ואכלת שם לפני יהוה אלהיך } \\
& \text { ושמחת אתה וביתך }
\end{aligned}
$$

${ }^{24} \mathrm{But}$ if the journey is too long for you, if you are not able to convey it, because the place where YHWH your God will choose to establish his name is too far from you, because YHWH your God has blessed you, ${ }^{25}$ then you may sell [your tithes and firstlings] for money and bind the money in your hand and go to the place that YHWH your God will choose, ${ }^{26}$ and spend the money on whatever you want: cattle, small livestock, wine, strong drink, or anything you wish, and you shall eat there 
before YHWH your God, and you shall rejoice, you and your

household.

By permitting the sale of firstlings (as well as tithes), and thus their inclusion in the mundane local economy, this concession stands in tension with Deut 12:17-18, which had carefully excluded tithes, firstlings, and certain other offerings from non-cultic use. Deuteronomy 14:26b returns to the language of Deut 12:17-18:

\section{Deuteronomy 12:18}

\begin{tabular}{|c|c|c|}
\hline A & אלהיך לפני יהוה & Instead, before YHWH your God \\
\hline B & $\begin{array}{r}\text { אשכלנו במקום יבחר יהוה } \\
\text { אלהיך בו }\end{array}$ & $\begin{array}{l}\text { you shall eat the aforementioned in the } \\
\text { place that YHWH your God will choose, }\end{array}$ \\
\hline C & 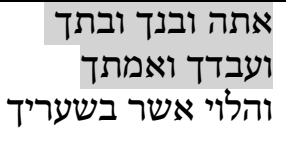 & $\begin{array}{l}\text { you, your son, your daughter, your male } \\
\text { slave, your female slave, and the local } \\
\text { Levite, }\end{array}$ \\
\hline $\mathrm{D}$ & אלהמחת לפני יהוה & $\begin{array}{l}\text { and you shall rejoice before YHWH your } \\
\text { God in all your undertakings. }\end{array}$ \\
\hline
\end{tabular}

Deuteronomy 14:26b

\begin{tabular}{lrl}
\hline$B^{\prime}$ & ואכלת שם & And you shall eat there \\
\hline$A^{\prime}$ & לפני יהוה אלהיך & before YHWH your God \\
\hline$D^{\prime}$ & ושמחת & And you shall rejoice \\
\hline$C^{\prime}$ & Yתה וביתד & You and your household ${ }^{6}$ \\
\hline
\end{tabular}

Rather than referring to the consumption of firstlings, tithes, and other sacrificial foods, Deut 14:26b stipulates that the substitute meal permitted by vv. 24-26a is to be eaten before YHWH. By echoing Deut 12:18 and Deut 14:23a, Deut 14:26 equates the substitute meal with the firstling/tithe meal it replaces.

Deuteronomy then provides a separate firstling law (Deut 15:19-23). This law requires that firstlings be eaten in a sacrificial

5 In Deut 14:26, שם ("there”) refers back to המקום אשר יבחר יהוה אלהיך בו ("the place that YHWH your God will choose”), found at the end of Deut 14:25.

${ }^{6}$ The list of household members to be included in a feast is also abbreviated as ביתך ("your household”) in Deut 12:7; 15:20. J. Stackert suggests that the term בתיכם ("your households") in Deut 12:7 could include the local Levite as well as family members (Rewriting the Torah: Literary Revision in Deuteronomy and the Holiness Legislation [FAT, 52; Tübingen: Mohr Siebeck, 2007], 171 n. 16). 
context (Deut 15:19-20) unless they are blemished (vv. 21-23).7 Most relevant are the requirements for unblemished firstlings:

$$
\begin{aligned}
& 19 \text { כל הבכור אשר יולד בבקרך ובצאנך הזכר תקדיש ליהוה אלהיך }
\end{aligned}
$$

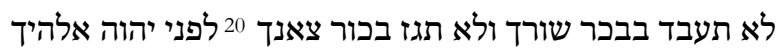

$$
\begin{aligned}
& \text { תאכלנו שנה בשנה במקום אשר יבחר יהוה אתה וביתך ולפור }
\end{aligned}
$$

${ }^{19}$ Every firstling that is born in your herd and your flock that is male, you shall set aside as sacred to YHWH your God. You shall not work your firstling ox or shear your firstling sheep/goat. ${ }^{20}$ You shall eat it annually before YHWH your God, in the place that YHWH will choose-you and your household.

Deuteronomy 15:19-20 reiterates the requirement of Deut 12:17-18 that firstlings be consumed in a sacral meal at YHWH's one chosen sanctuary, providing additional clarifications and justification. Deuteronomy 15:19 requires that firstlings be set aside as sacred (Hiphil) and prohibits their use for traction and wool: these prohibitions probably function as a merism, implying a ban on all economic use of firstlings. ${ }^{8}$ The command to separate firstlings and the prohibitions of their economic use go beyond the letter of Deut 12:17-18: firstlings are not only barred from local consumption but completely excluded from the local economic sphere. The qualification of בכור "firstling" with ה ה "every" in v. 19 implies that the requirements to sanctify sacrificable firstlings, exclude them from economic use, and consume them in a cultic meal are without exceptions. ${ }^{9}$ Deuteronomy 15:20 then echoes Deut 12:18 to reassert its demand:

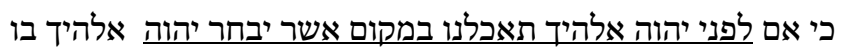

$$
\begin{aligned}
& \text { אתה ובנד ובתד ועבדד ואמתך והלוי אשר בשעריב ושמחת לפני } \\
& \text { יהוה אלהיך בכל משלח ידך }
\end{aligned}
$$

${ }^{7}$ Unlike other biblical legal corpora, Deuteronomy does not explicitly regulate the firstlings of unclean animals (cf. Exod 13:2, 13-15; Lev 27:27) or firstborn human sons (cf. Exod 13:2, 13-15; 22:28b).

${ }^{8}$ Cf. Georg Braulik, Deuteronomium 1-16,17 (NEchtB, 15; Würzburg: Echter, 1986), 115; Duane L. Christensen, Deuteronomy 1:1-21:9, Revised (WBC, 6A; Nashville: Thomas Nelson Publishers, 2001), 325; William S. Morrow, Scribing the Center: Organization and Redaction in Deuteronomy 14:117:13 (SBLMS, 49; Atlanta: Scholars Press, 1995), 123-24; Richard D. Nelson, Deuteronomy: A Commentary (OTL; Louisville: Westminster John Knox, 2002), 200; Eduard Nielsen, Deuteronomium (HAT, I.6; Tübingen: Mohr Siebeck, 1995), 164; Otto, Deuteronomium 12,1-23,15, 1369; Seitz, Deuteronomium, 188.

${ }^{9}$ For כל with "the determinate singular of a noun of species or category," see $J M \$ 139 g$. 
Instead, you shall eat it before YHWH your God in the place that YHWH your God will choose-you, your son, your daughter, your male slave, your female slave, and the local Levite. You shall rejoice before YHWH your God in all of your undertakings. (Deut 12:18)

לפני יהוה אלהיך תאכלנו שנה בשנה במקום אשר יבחר יהוה אתה

וַבַיתַּד10

You shall eat it annually before YHWH your God, in the place that YHWH will choose-you and your household. (Deut 15:20)

The strict requirements of Deut 15:19-20 stand in tension with the concession of Deut 14:24-26, which does allow for some exceptions. The absolute nature of Deut 15:19-20 may also explain why a clarification about blemished firstlings was included in vv. 21-23: the general laws of sacrifice in Deut 12:1-28 surely assumed that blemished animals were ineligible for sacrifice, but the insistence of Deut 15:19-20 that absolutely all male firstling animals must be offered gave rise to the possible misunderstanding that this included even blemished animals.

The major tension that emerges in a synchronic reading of Deuteronomy's regulations for firstlings is whether they must absolutely be consumed in a sacrificial context or whether exceptions can be made in light of the problem of distance. Deuteronomy 12:17-18 and Deut 15:19-20 agree that firstlings are not to be utilized in any non-cultic context, although Deut 15:19-20 provides more detail and is perhaps stricter than Deut 12:17-18. Deuteronomy 12:17-18, which prohibits the local slaughter of firstlings, and Deut 14:24-26, which permits the sale of firstlings and thus their non-cultic use, stand in tension. This tension can be resolved by reading Deut 14:24-26 as providing an exception to Deut 12:17-18, and the verbal resumptions of Deut 12:17-18 in Deut 14:23a and 26b implicitly frame Deut 14:24-26 as just such an exception. It is more difficult to read Deut 14:24-26 as an exception to the stricter and more detailed requirements of Deut 15:19-20. A concession allowing the sale of firstlings cannot be reconciled with a command to sanctify firstlings and a ban of their local economic use.

To resolve the lingering tension between Deut 14:24-26 and Deut 15:19-20, one of the texts must be read against its plain sense. A number of premodern interpreters did exactly this, interpretively limiting the concession of Deut 14:24-26 to tithes only and thereby assimilating it to Deut 15:19-20. Others left the tension unresolved. Modern scholars have responded similarly, either removing firstlings from Deut 14:24-26 or letting the tension stand. I turn briefly to the

10 For ובנך ובתך ועבדך ואמתך as an abbreviation of אתם (והלוי אשר בשעריך) see Deut 14:26 and cf. the plural equivalent (וברך) ובתיכם (וריד in Deut 12:7. 
history of interpretation of these passages before examining Deuteronomy's firstling regulations from a diachronic perspective.

\section{HISTORY OF INTERPRETATION: ASSIMILATING DEUTER- ONOMY 14:24-26 TO DEUTERONOMY 15:19-20}

Ancient and modern readers have resolved the tension between Deut 14:24-26 and Deut 15:19-20 by assimilating Deut 14:24-26 to Deut 15:19-20. Ambiguities in Deut 14:24-26, and the relative clarity and explicitness of Deut 15:19-20, can explain this tendency. Deuteronomy 15:19-20 is unequivocally a text about firstlings and what must be done with them. Deuteronomy 14:24-26 is less clear. The pericope of which it is a part, Deut 14:22-29, shifts topics from tithes alone (v. 22), to tithes and firstlings (v. 23), and back to tithes (vv. 28-29). ${ }^{11}$ Firstlings are not mentioned explicitly in the concession of Deut 14:24-26 itself. A pronominal suffix in v. 24 ( לא תוכל "you are not able to convey it') and an implied object in v. 25 (ונתתה "then you may sell [it]") refer the reader back to "the tithe of your grain, your wine, and your oil, and the firstlings of your herd and your flock" in v. 23. Because the concession lacks explicit references to firstlings, and much of the surrounding passage focuses on tithes, it is not difficult to see why readers might have read the concession as applying only to tithes. Many readers did exactly this, thereby eliminating the tension between Deut 14:24-26 and 15:1920.

The Temple Scroll reads the concession of Deut 14:24-26 as applying to tithes but not firstlings. Temple Scroll column 43 quotes Deut 14:24-26, in abbreviated and modified form. This column regulates the consumption of certain sacred vegetable foods, probably tithes. ${ }^{12}$ Conversely, Column 52, which contains the Temple

${ }^{11}$ Gershon Brin, “ 'Double' Laws in the Bible: The Development of Some Biblical Laws," in Studies in Biblical Law: From the Hebrew Bible to the Dead Sea Scrolls, trans. Jonathan Chipman (JSOTSup, 176; Sheffield: JSOT Press, 1994), 20-51, 34; Andrew D.H. Mayes, Deuteronomy (NCB; London: Marshall, Morgan \& Scott, 1979), 245; Morrow, Scribing the Center, 83-85; Nelson, Deuteronomy, 186; Gerhard von Rad, Deuteronomy: A Commentary, trans. Dorothea Barton (OTL; Philadelphia: Westminster, 1966), 103; Eleonore Reuter, Kultrentralisation: Entstehung und Theologie von Dtn 12 (BBB, 87; Frankfurt am Main: Hain, 1993), 158; Seitz, Deuteronomium, 192. Some have suggested that Deut 14:23 refers to a tithe of vegetable produce along with a tithe of firstlings (Peter Altmann, Festive Meals in Ancient Israel: Deuteronomy's Identity Politics in Their Ancient Near Eastern Context [BZAW, 424; Berlin: de Gruyter, 2011], 214; Christensen, Deuteronomy 1:1-21:9, 304).

12 See Sidnie White Crawford, The Temple Scroll and Related Texts (Companion to the Qumran Scrolls, 2; Sheffield: Sheffield Academic, 2000), 5354; Lawrence H. Schiffman, "The Sacrificial System of the Temple Scroll and the Book of Jubilees," in Florentino García Martínez (ed.), The Courtyards of the House of the Lord: Studies on the Temple Scroll (STDJ, 75; Leiden: Brill, 2008), 99-122, 114; Lawrence H. Schiffman, "Priestly and Levitical Gifts in the Temple Scroll," in Florentino García Martínez (ed.), The Courtyards of the House 
Scroll's firstling regulations, cites Deut 15:19-20 but makes no reference to Deut 14:24-26. The inclusion of the concession in the context of tithe regulations but not in the context of firstling regulations represents an interpretation of Deut 14:24-26, against its plain sense, as applying only to vegetable tithes.

Targums Neofiti and Pseudo-Jonathan explicitly supply "tithe" as a verbal object in the concession of Deut 14:24-26, thereby assimilating it to Deut 15:19-20. Targum Neofiti supplies מעשרה "the second tithe" in both Deut 14:24 and 25:

$$
\begin{aligned}
& 24 \text { ארום יסגי מנכון אורחה ארום לית אתון יכלין למס'ברה מעשרה }
\end{aligned}
$$

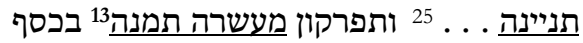

${ }^{24}$ If the way is too great for you, so that you are not able to carry the second tithe, $\ldots{ }^{25}$ then you shall redeem the second tithe for money ... ${ }^{14}$

Similarly, Targum Pseudo-Jonathan supplies ית מעשרא "the tithe (accusative)" in v. 24. It leaves the object implicit in v. 25, imitating the Masoretic text, but because "the tithe" was supplied in v. 24, it also stands as the implicit object of v. 25. Targum Pseudo-Jonathan also adds "second tithe" in v. 23 , which already explicitly mentions tithes and firstlings:

$$
\begin{aligned}
& 23 \text { ותיכלון מעשרא תיניינא קדם ייי אלקכון באתר\}ע\{א דיתרעי }
\end{aligned}
$$

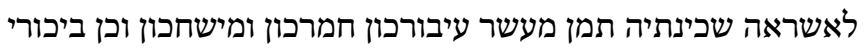

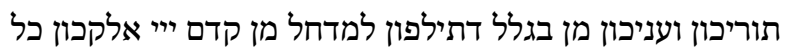

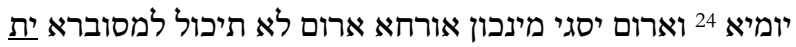

$$
\begin{aligned}
& \text { מעשרא ... } 25 \text { ותחליל בכספא יניון }
\end{aligned}
$$

${ }^{23}$ And you shall eat the second tithe before YYY your God, in the place where he will choose to make his Shekbinah dwell: the tithe of your grain, wine, and oil. And thus (for) the firstlings of your oxen and your small cattle, in order that you learn to fear YYY your God forever. ${ }^{24}$ And if the journey is too great for you, so that you are not able to carry the tithe, $\ldots{ }^{25}$ then you will redeem [the tithe] for money.

The view that Deut 14:24-26 applied only to tithes is reflected in other premodern interpretations as well as some modern ones. Sifre Deuteronomy $\$ 107$ comments on Deut 14:24-26, making frequent

of the Lord: Studies on the Temple Scroll (STDJ, 75; Leiden: Brill, 2008), 541-56, $549-50$.

13 תמנה (cf. CAL: http://cal1.cn.huc.edu/get_a_chapter.php?file $=54001 \&$ sub $=514 \& c s e t=$ $\mathrm{H})$.

${ }^{14}$ The concept of the "second tithe" was invented by interpreters to deal with the discrepancies between Deut 14:22-26 and Num 18:20-32 (see Stackert, Rewriting the Torah, 167). 
mention of the "second tithe" but never discusses firstlings at all. Ibn Ezra's interpretation of Deut 14:24-26 is similar: he suggests that "tithe" in v. 23 is the implied object of ונתתה ("then you may sell") in v. 25..$^{15}$ Many modern readers exclude firstlings from the concession of Deut 14:24-26 as well, though some interpret it as applying to both tithes and firstlings. ${ }^{16}$ With respect to firstlings, many readers have effectively read Deut 14:24-26 not on its own terms but on terms dictated by Deut 15:19-20.

\section{DiACHRONIC DEVELOPMENT OF DEUTERONOMY'S FIRSTLING LEGISLATION}

As shown above, in a synchronic reading of Deuteronomy's firstling regulations, the concession of Deut 14:24-26 can be read into Deut 12:17-18. The ancient and modern interpretations surveyed above show how Deut 15:19-20 can be (and has been) imposed on Deut 14:24-26. The ability of synchronic readers to resolve the tensions among Deuteronomy's firstling regulations does not negate those tensions. Rather, as the following diachronic analysis will demonstrate, it reflects the designs of secondary authors who wrote their texts to amend existing texts. Deuteronomy 12:17-18 represents the earliest of the firstling regulations. At this stage, both firstlings and tithes were excluded from the new concession of local non-cultic slaughter (Deut 12:15-16) and had to be consumed in cultic meals. A later author composed Deut 14:24-26 to introduce an exception to Deut 12:17-18: for those living far from the cult site, both tithes

15 See Abraham ben Meïr Ibn Ezra, The Commentary of Abraham Ibn Eqra on the Pentateuch, trans. Jay F. Shachter, vol. 5: Deuteronomy (Hoboken, NJ: Ktav Publishing House, 2003), 67.

16 Among those who read Deut 14:24-26 as a concession exclusively for tithes are Braulik, Deuteronomium, 109; Brin, " 'Double' Laws," 34; Calum M. Carmichael, The Laws of Deuteronomy (Ithaca, NY: Cornell University Press, 1974), 83; Samuel Rolles Driver, A Critical and Exegetical Commentary on Deuteronomy (ICC; Edinburgh: T\&T Clark, 1973), 167; Paul Heger, The Three Biblical Altar Laws: Developments in the Sacrificial Cult in Practice and Theology: Political and Economic Background (BZAW, 279; Berlin: de Gruyter, 2011), 295 n. 35; Reuter, Kultzentralisation, 164; Seitz, Deuteronomium, 194-95; Rannfrid I. Thelle, Approaches to the Chosen Place: Accessing a Biblical Concept, (LHBOTS, 564; London: T\&T Clark, 2012), 75 n. 21; Julius Wellhausen, Prolegomena to the History of Israel, trans. Allan Menzies and J. Sutherland Black (New York: Meridian Books, 1957), 156. Cf. the Revised Standard Version, which supplies tithe in v. 24: "And if the way is too long for you, so that you are not able to bring the tithe ..."

Several scholars have recognized that the exemption of Deut 14:24-26a applies to both tithes and firstlings (Bernard M. Levinson, "Deuteronomy," in Adele Berlin and Marc Zvi Brettler [eds.], The Jewish Study Bible [New York: Oxford University Press, 2004], 356-450, 398; Jacob Milgrom, Leviticus 1-16: A New Translation with Introduction and Commentary [AB, 3; New York: Doubleday, 1991], 288; Moshe Weinfeld, Deuteronomy and the Deuteronomic School [Oxford: Clarendon, 1972], 215). 
and firstlings could now be sold to finance a substitute cultic banquet. A still later writer added Deut 15:19-20 to reduce the scope of the exception of Deut 14:24-26 and to reinstate in part the regulation of Deut 12:17-18: with the addition of Deut 15:19-20, tithes could be sold (in accordance with 14:24-26) but firstlings must be delivered to the cult site (in accordance with 12:17-18). The following diachronic reconstruction shows how the authors of Deut 14:24 26 responded to Deut 12:17-18 and how the author of Deut 15:19_ 20 responded to both of those texts. Before comparing the texts, I introduce and answer a related diachronic question: are firstlings integral and original to Deut 14:23, and thus to the concession of Deut 14:24-26? If the concession was meant to apply to tithes, then the tension between Deut 14:24-26 and 15:19-20 could be resolved by restoring the original, correct text of Deut 14:24-26.

\section{THE INCLUSION OF FIRSTLINGS IN THE CONCESSION OF DEUTERONOMY 14:24-26}

Several scholars have argued that Deut 14:23 (and hence the concession of Deut 14:24-26) originally applied only to tithes, regarding the inclusion of firstlings in Deut 14:23 as secondary, accidental, or both. ${ }^{17}$ According to this view, the text was (mistakenly or intentionally) assimilated to Deut 12:17, in which tithes and firstlings are listed consecutively: מעשר דגנך ותירשך ויצהרך ובכרת בקרך וצאנך "the tithe of your grain, your wine, and your oil, and the firstlings of your herd and your flock." If the inclusion of firstlings is an error or interpolation, then we can recover a more original text of Deut 14:23 by excising the reference to firstlings. Such an emendation would eliminate the contradiction between Deut 14:24-26 and Deut 15:1920 and eliminate the topical fluctuation within Deut 14:22-29, which would deal exclusively with vegetable tithes. However, text-critical, grammatical, innertextual, and intertextual evidence all suggest that firstlings are integral to the concession of Deut 14:24-26.18

All extant textual witnesses represent the phrase ובכרת בקרך וצאנך "and the firstlings of your flock and your herd." Even Targums Pseudo-Jonathan and Neofiti, which exegetically excluded firstlings from the concession of Deut 14:24-26 (see above), included the phrase in Deut 14:23. The Septuagint goes in the opposite direction, strengthening the tie between the mention of firstlings in v. 23 and the concession of vv. 24-26. The Septuagint connects

\footnotetext{
${ }^{17}$ Mayes, Deuteronomy, 245; Jacob Milgrom, Leviticus 23-27: A New Translation with Introduction and Commentary (AB, 3B; New York: Doubleday, 2001), 2399; Nelson, Deuteronomy, 185; Seitz, Deuteronomium, 194, see Seitz, 194 n. 296 for additional references.

18 For more detailed arguments on this point, see Kevin Mattison, Rewriting and Revision as Amendment in the Laws of Deuteronomy (FAT, 2.100; Tübingen: Mohr Siebeck, 2018), 102-15.
} 


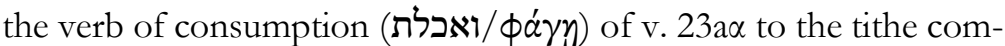
mand of v. 22 and adds a new verb, ol' $\sigma \varepsilon \tau \varepsilon$ "you shall bring." 19 The tithe and firstling list of v. 23 is the subject of ol $\sigma \varepsilon \tau \varepsilon$. This verb of bringing (a future-tense form of $\phi \varepsilon ́ p \omega$ ) connects the tithe and firstling list to one of the conditions of v. 24: "לא תוכל שאתו

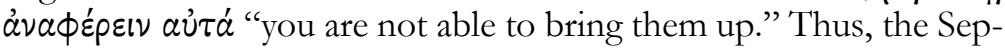
tuagint translator understood the concession as including both tithes and firstlings.

Grammatically and semantically, the term שאתו "to carry it" in Deut 14:24 might seem to be better suited to a reference to tithes alone than to tithes and firstlings. Singular pronouns most often refer to singular nouns, but can be used to refer to compound noun phrases, even those containing plural nouns. Such a construction is found in Deut 12:17-18, in which a suffixed pronoun ("you shall eat the aforementioned"]) refers back to a long list of sacrifices that includes the tithes and firstlings found in Deut 14:23.20 נשא ("to carry") often refers to the transportation of inanimate objects. ${ }^{21}$ But נשא can also be used to refer to the conveyance of animals, as in Deut 12:26, where it denotes the conveyance of sacrificial animals to the cult place:

רק קדשיך אשר יהיו לך ונדריך תשא ובאת אל המקום אשר יבחר

יהוה

But your sacred [animals] and your votive offerings you shall bring and go to the place that YHWH will choose. ${ }^{22}$

In short, the verb נשא and its singular object suffix do not necessarily reflect an original concession for tithes alone.

The legal reasoning of Deut 14:23-26, including the cultic meal described in v. 23 and the substitute meal in v. 26, fits a concession that includes both tithes and firstlings. As several scholars have sug-

${ }^{19}$ For discussion of this and other variants in Deut 14:23, see Carmel McCarthy, "Commentary on the Critical Apparatus," in Deuteronomy (BHQ, 5; Stuttgart: Deutsche Bibelgesellschaft, 2007), 49*-169*, 97*.

${ }^{20}$ Morrow notes the parallel construction (Scribing the Center, 17, $78 \mathrm{n}$. 3). Udo Rüterswörden adduces Deut 21:10; 28:48 as further examples of this construction (Deuteronomium $(12,1-13,1)$ [BKAT, V/3.1; NeukirchenVluyn: Neukirchener Verlag, 2011], 57).

21 See Ludwig Köhler and Walter Baumgartner, "נשא,, in HALOT, 724 (definition 1).

22 According to Menahem Haran, קדשים was “apparently a comprehensive term for all those offerings which could not be desanctified and made profane" (Temples and Temple-Service in Ancient Israel: An Inquiry into Biblical Cult Phenomena and the Historical Setting of the Priestly School [Winona Lake, IN: Eisenbrauns, 1985], 16 n. 5). If Haran is correct, Deut 12:26 would mandate the conveying of firstlings to the cult site. 
gested, it would be impractical to consume ten percent of one's harvest in a single meal. ${ }^{23}$ The consumption of firstlings in a single feast might be more realistic. Other tithe and firstling texts substantiate this contrast. Priestly/Holiness regulations suggest that firstlings could be consumed by Priests in a single cultic meal (Num 18:1718), but tithes could sustain the Levites (a much larger group than priests) throughout the year (Num 18:30-32). ${ }^{24}$ The Temple Scroll also allows tithes to be eaten on multiple feast days throughout the year, which may also reflect the impossibility of consuming the tithe in a single feast (11QT 43). Moreover, the list of potential substitute meal items in Deut 14:26 suggests that firstling animals were a more natural basis for a cultic banquet. The list of possible foods for the substitute cultic meal does not include grain or oil, perhaps because these ingredients could not serve as the basis of a cultic feast. ${ }^{25}$ Livestock, on the other hand, is entirely appropriate to this function, thus cattle and sheep/goats are included in the list of foods that can be

${ }^{23}$ Mayes, Deuteronomy, 246; J.G. McConville, Law and Theology in Deuteronomy (JSOTSup, 33; Sheffield: JSOT Press, 1984), 72-73; Nelson, Deuteronomy, 186; Nielsen, Deuteronomium, 157; Rad, Deuteronomy, 103; Seitz, Deuteronomium, 194; see further McConville, Law and Theology in Deuteronomy, 170 n. 8. Alternatively, מעשר (and the verb עשר) may not indicate a literal "tenth" in Deuteronomy but either a more general "levy" or a "festive banquet." See Joseph M. Baumgarten, "On the Non-Literal Use of Ma ăśér/ Dekate," JBL 103 (1984), 245-51; Henk Jagersma, "The Tithes in the Old Testament," in Remembering All the Way: A Collection of Old Testament Studies Published on the Occasion of the Fortieth Anniversary of the Oudtestamentisch Werkegezelschap in Nederland (OtSt, 21; Leiden: Brill, 1981), 116-28, 118; Stackert, Rewriting the Torah, 169-70, 170 n. 11; cf. Gregorio del Olmo Lete, Joaquín Sanmartín and Wilfred G.E. Watson, A Dictionary of the Ugaritic Language in the Alphabetic Tradition (2nd revised edition; HdO, 67; Leiden/Boston: Brill, 2004), 188 (/ $/$ ^-š-r/), 190 ('Šrt [T]).

24 These laws evince a completely different world view from Deuteronomy's tithe and firstling laws. In general, in the Priestly/Holiness conception, a hierarchy strictly separates priests from Levites (see Christian Frevel, "Ending with the High Priest: The Hierarchy of Priests and Levites in the Book of Numbers," in Christian Frevel, Thomas Pola and Aaron Schart [eds.], Torah and the Book of Numbers [FAT, 2.62; Tübingen: Mohr Siebeck, 2013], 138-63). In this case another significant difference is that tithes and firstlings are donated rather than being consumed by the offerer. Nevertheless, the regulations in Numbers 18 suggest that tithes represented a substantial food source that could sustain a relatively large group (Levites) throughout the year, whereas firstlings could be consumed by a relatively small group (priests) in a single meal.

${ }^{25}$ Nielsen notes that the list includes processed products like wine and beer instead of harvested, unprocessed produce like grain and oil (Deuteronomium, 157). But the incongruities between the tithe demand and the substitute meal list are more fundamental than this. If the list consisted of processed foods that correspond to tithed produce, we might expect bread to be listed, but instead grain is not represented in any form. 
purchased. More generally, meat (along with alcohol) was a centerpiece of any festive meal. ${ }^{26}$ The Temple Scroll, which allows only the sale of tithes, adds grain and oil to the substitute meal list and puts these added elements, along with wine, at the beginning of the list (11QT 43.14-15), thereby establishing a closer correspondence between the normally-required tithe offering and what can be substituted for it.

Deuteronomy 14:22-26 responds not only to Deut 12:17-18 but also to Exod 22:28-29:

\section{8 מלאתך ודמעך לא תאחר בכור בניך תתן לי 29 כן תעשה לשרך לצאנך שבעת ימים יהיה עם אמו ביום השמיני תתנו לי}

${ }^{28}$ Your fullness and your dripping you shall not delay. The firstborn of your sons you shall give to me. ${ }^{29}$ You shall do likewise for your ox (and) your sheep: seven days it shall be with its mother; on the eighth day you shall give (it) to me.

The details of these provisions as well as larger intertextual considerations suggest that Deuteronomy depends on this passage for the formulation of its tithe law. In Exod 22:28-29, the deity demands an obscure vegetable offering (Exod 22:28a) and the firstborn of Israel's sons (v. 28b) and livestock (v. 29). Variety in ancient understandings of Exod 22:28a illustrate the obscurity of this half-verse and provide some parallels to Deuteronomy's "discovery" of a tithe law there:

\begin{tabular}{|c|c|}
\hline Septuagint & 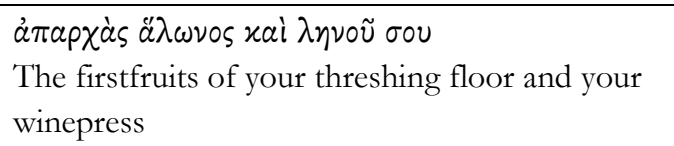 \\
\hline $\begin{array}{l}\text { Targum Pseudo- } \\
\text { Jonathan }\end{array}$ & $\begin{array}{l}\text { ביכורי פירד וביכורי חמר נעווך } \\
\text { The firstfruits of your produce and the } \\
\text { firstfruits of the wine of your winepress }\end{array}$ \\
\hline Targum Neofiti & Your tithes and your offering משרתכון ודמעכון \\
\hline Targum Onkelos & Your firstfruit and your offering \\
\hline Samaritan Targum & Your fullness and your offering \\
\hline Peshitta & $\begin{array}{l}\text { The firstfruits of the produce of your threshing } \\
\text { floor and the firstfruits of your winepress }\end{array}$ \\
\hline Vulgate & $\begin{array}{l}\text { decimas tuas et primitias } \\
\text { Your tithes and firstfruits }\end{array}$ \\
\hline
\end{tabular}

Figure 1. Premodern understandings of ממע and

${ }^{26}$ Altmann, Festive Meals, 217. 
Whatever these terms might have originally meant, the variety of the translations suggests that their meanings were unclear, and the translations of Targum Neofiti and the Vulgate suggest that it would not have been so strange for Deuteronomy's authors to read a reference to the tithe in Exod 22:28a.

The demands of Exod 22:28-29 correspond conceptually to the demands of Deut 14:23: each juxtaposes requirements of vegetable offerings (tithes) and animal firstlings. Deuteronomy 14:22-23 have not typically been identified as reformulations of Exod 22:2829 because they lack any verbal parallels. ${ }^{27}$ Nevertheless, the similar constellation of topics is likely a sign of dependence. Moreover, Deut 14:21 also reformulates Exod 22:30, so Deut 14:21-23 can be understood as a reworking of Exod 22:28-30. ${ }^{28}$ Finally, Exod 22:2829 would be one of many laws of the Covenant Code (Exod 20:2223:19) that is reworked by Deuteronomy: the law of centralization that opens Deuteronomy's law code (Deut 12:1-28) reworks the Covenant Code's altar law (Exod 20:24-26), and from this starting point Deuteronomy systematically reformulates laws of the Covenant Code in light of cultic centralization. ${ }^{29}$

Deuteronomy 14:22 reformulated Exod 22:28a as an explicit tithe law, which necessitated a near-complete break from the source's language. ${ }^{30}$ The Covenant Code lacks any explicit legislation for the tithe. ${ }^{31}$ This lacuna is significant in light of the inclusion of

27 Wellhausen notes the strong conceptual correspondence between Exod 22:28-29 and Deut 14:22-23 without explicitly suggesting that the latter revises the former: "[A] gift of the first and best of corn, wine, and oil ... which is conjoined with the firstlings of cattle and sheep ... In a precisely similar way the tithe of the field stands conjoined with the firstlings of cattle in Deuteronomy" (Prolegomena, 157).

${ }^{28}$ Van Seters notes the close correspondences between Deut 14:21-23 and Exod 22:28-30 but suggests dependence in the opposite direction (Law Book for the Diaspora, 145).

${ }_{29}$ On the relationship between Deuteronomy 12 and the Covenant Code's altar law, see Levinson, Deuteronomy and the Hermeneutics, 23-52; Mattison, Rewriting and Revision, 29-86. On Deuteronomy as a reworking of the Covenant Code see, among others, Eckart Otto, "History of the LegalReligious Hermeneutics of Deuteronomy from the Assyrian to the Hellenistic Period," in Anselm H. Hagedorn and Reinhard G. Kratz (eds.), Law and Religion in the Eastern Mediterranean: From Antiquity to Early Islam (Oxford: Oxford University Press, 2013), 212-23. For a list of laws of Deuteronomy influenced by the Covenant Code, see David P. Wright, Inventing God's Law: How the Covenant Code of the Bible Used and Revised the Laws of Hammurabi (New York: Oxford University Press, 2009), 506-7.

${ }^{30}$ For a summary of the variety in Deuteronomy's responses to the laws of the Covenant Code, which range from verbatim repetition, to the echoing of key terms, to significant expansion, to complete recasting, see Driver, Deuteronomy, viii, with examples on viii-x.

31 Driver, Deuteronomy, 166, 169; Nelson, Deuteronomy, 184; Nielsen, Deuteronomium, 156; Eckart Otto, Das Deuteronomium: politische Theologie und Rechtsformen in Juda und Assyrien (BZAW, 284; Berlin/New York: de Gruyter, 
tithes in the other law collections (Lev 27:30-32; Num 18:21-32; Deut $12: 17-18 ; 14: 22-29 ; 26: 12-15)$ and references to tithing in narratives (Gen 14:20; 28:22; cf. the royal tithe of 1 Sam 8:15,17) and prophecy (Amos 4:4). Milgrom speculates that Exod 22:28a might actually have been a tithe law. ${ }^{32}$ After Deuteronomy reformulated Exod 22:28a into a clear tithe law (Deut 14:22), Deut 14:23 called for the centralization of tithes and firstlings, and did so using the centralization-oriented verbiage of Deut 12:17-18 rather than the language of the Covenant Code. Deuteronomy 14:22-26 as a whole responded to two texts that juxtapose animal firstlings and a vegetable tithe or other mandatory vegetable offering (Exod 22:28-29 and Deut 12:17-18) to complement the centralized cult with a concession to distance that likewise included both animal firstlings and vegetable tithes.

\section{DEUTERONOMY 14:24-26: AN AMENDMENT TO DEUTERONOMY 12:17-18}

Deuteronomy 12:17-18 presents the requirement to consume tithes and firstlings at the sanctuary as an exclusion to the concession of local slaughter (vv. 15-16), which is itself an exception to the main requirement of centralized sacrifice (vv. 13-14). There is no indication that this exclusion allows any further exceptions. The problem of distance, addressed for most sacrifices (v. 15), remains unresolved for the offerings included in Deut 12:17-18. A later author composed Deut 14:24-26 to amend Deut 12:17-18 and resolve the problem of distance for the specific cases of tithes and firstlings. This author used verbal echoes of Deut 12:17-18 (Deut 14:23a, 26b) to frame a concession that circumvented the requirements of Deut 12:17-18, providing a circuitious new method for fulfilling the requirement of a cultic meal while easing but not eliminating the burden on Israelites living far from the cult site: tithes and firstlings need not be conveyed to the cult site, but the journey must still be made. The concession of tithe and firstling sale thereby continues the work of the earlier concession of local slaughter: both concessions complement and support the now-centralized cult, eliminating potential problems caused by the loss of local sanctuaries and thereby eliminating potential reasons to perpetuate or revert to a geographicallydistributed sacrificial cult. ${ }^{33}$

The introduction of the tithe and firstling concession in Deut 14:23a consists almost entirely of verbiage shared with Deut 12:17-

1999), 316.

${ }^{32}$ Leviticus 23-27, 2432.

${ }^{33}$ On the role of local slaughter as a reinforcing complement to centralized sacrifice, see Mattison, Rewriting and Revision, 61-66, 81-82. On the role of concessions in Deuteronomy in general, see Kevin Mattison, "Deuteronomy's 'Law of the King' and the Judicial Role of Ancient Near Eastern Kings," in Bill T. Arnold and Harald Samuel (eds.), The Politics of Deuteronomy (FAT, 2; Tübingen: Mohr Siebeck, forthcoming). 
18. This quotation is selective and rearranges quoted material: Deut 14:23a effectively makes tithes and firstlings a pair, whereas in Deut 12:17 tithes and firstlings are merely two contiguous members of a five-item list. This exclusive pairing of tithes and firstlings is unparalleled in the Hebrew Bible. ${ }^{34}$ The basic point of Deut 12:17-18 remains intact: certain offerings can only be offered or consumed at the cult site in a cultic meal. Verbal and conceptual echoes set the stage for the significant departure from Deut 12:17-18 that follows.

That departure comes in the concession of Deut 14:24-26a, which permits Israelites living far from the cult site to sell firstlings (as well as tithes), travel to the sanctuary, and use the proceeds to purchase the banquet that the tithes and firstlings otherwise would have provided. The concession builds on the concession of local slaughter (Deut 12:15-16, 20-25): both concessions address the needs of those far from the cult site. By allowing some Israelites to sell their firstlings, however, Deut 14:24-26a diverges from Deut 12:17-18, which explicitly required that all Israelites consume their firstlings in cultic banquets at the one chosen sanctuary.

The concession of Deut 14:24-26 differs from the concession of local slaughter in that it results in a cultic meal, thereby preserving, albeit indirectly, the tie between firstlings and the cult site. ${ }^{35}$ Theoretically, the author could have simply expanded the concession of secular slaughter to include firstlings, but this would have had two deleterious effects. First, it would have contravened Deut 12:17-18 in a blatant way rather than providing a way around it. Second, it would have completely severed firstlings from their cultic context, eliminating altogether the cultic meal they should have provided.

\footnotetext{
${ }^{34}$ Morrow observes that the pairing of tithes and firstlings, in that order, is unique to Deuteronomy (Scribing the Center, 214-15). Outside of Deuteronomy, the and firstlings appear only in separate laws:

\begin{tabular}{|l|l|}
\hline tithes & Lev 27:30-32; Num 18:21-32 \\
\hline firstlings & Exod 13:1-2,11-6; 22:28b-29; 34:19-20; Lev 27:26- \\
& 27; Num 8:17; 18:15-18 \\
\hline
\end{tabular}
}

Even within Deuteronomy, the exclusive pairing of tithes and firstlings is unique to Deut 14:23-26. In Deut 12:17-18 they are merely the first two items in a five-item list. In the similar list of Deut 12:6, tithes and firstlings are not contiguous, which suggests that the author perceived no special connection between the two:

והבאתם שמה עלתיכם וזבחיכם ואת מעשרתיכם ואת תרומת ידכם

\section{ונדריכם ונדבתיכם ובכרת בקרכם וצאנכם}

And you shall bring there your burnt-offerings and your sacrifices, and your tithes and the contribution of your hand and your votive offerings and your freewill offerings and the firstlings of your cattle and your small livestock.

35 Cf. Milgrom, Leviticus 23-27, 2427; Jeffrey H. Tigay, Deuteronomy (JPS Torah Commentary; Philadelphia: Jewish Publication Society of America, 1996), 142, 151. 
Although the concession of Deut 14:24-26 avoids contradicting Deut 12:17-18 directly, is likely that firstlings, once sold, would have been subjected to non-cultic use, including local slaughter and consumption. ${ }^{36}$ (Likewise, sold tithes could presumably have been consumed in a local non-cultic meal.) The sale of tithes and firstlings implies that the buyer would be able to use them, whether for traction, wool, or the basis of a local non-cultic meal. Moreover, restrictions imposed on the proceeds of the firstling (or tithe) sale and on the foods purchased with it parallel the restrictions that would normally be imposed on the firstling itself and suggest a tacit transference of sacredness from the firstling to the money and finally to the substitute meal. One who sells a tithe or firstling must "bind up" (צור ) the proceeds, isolating it from one's other possessions, just as firstlings and tithes would be separated. ${ }^{37}$ The proceeds must then be brought to the cult site and used to purchase food and drink for a cultic banquet. The money cannot be used for other purposes, and neither can the substitute meal be acquired by other means. These restrictions mirror the enforced separation of tithes and firstlings elsewhere. In Deut 12:17-18, tithes and firstlings are excluded from consumption in the local context in which most foods can be consumed. In Deut 15:19, firstlings are set apart (קדשV Hiphil) and barred from economic use. Even the triennial tithe, which is to be used locally to feed the poor rather than brought to the sanctuary for a cultic banquet, must be kept separate from other produce (Deut $14: 28 ; 26: 13$ ) and is subject to special purity restrictions (Deut 26:14). In addition, the efficacy of the substitute cultic meal suggests that the sacredness of the firstling (or tithe) is transferred to the proceeds of its sale and ultimately to the food and drink purchased at the central sanctuary. The introduction of the substitute foods into the cultic sphere implies a concomitant releasing of the firstling (or tithe) into the local economic sphere. ${ }^{38}$

36 Cf. Braulik, Deuteronomium, 109; Rad, Deuteronomy, 103; Reuter, Kultzentralisation, 159; Weinfeld, Deuteronomy and the Deuteronomic School, 214 15.

37 Nelson suggests that וצרר הכסף בידד "bind up the money in your hand" serves to isolate the money and ensure it is spent on the central cultic meal (Deuteronomy, 186; cf. Tigay, Deuteronomy, 143).

38 Alexander Rofé aptly describes Deut 14:24-26 as "permitt[ing] the deconsecration of the tithe" ("The History of the Cities of Refuge in Biblical Law," in Sara Japhet [ed.], Studies in Bible: 1986 [Scripta Hierosolymitana, 31; Jerusalem: Magnes, 1986], 209-39, 215). Compare y. Ma'aśer Šeni, which speaks of "the second tithe, which implicates its substitute" (1:1) and asserts that "When [the second tithe] was bought, the holiness of the tithe left it" (1:3). Translations adapted from Heinrich W. Guggenheimer (ed.), The Jerusalem Talmud, First Order: Zeraïm, Tractates Ma'aser Seni, Hallah, 'Orlah, and Bikkurim, trans. Heinrich W. Guggenheimer, vol. 1.5 (SJ, 23; Berlin: de Gruyter, 2003), 4, 34. 
Deuteronomy 14:26b bookends the amendment of Deut 14:24-26a with a return to the language of Deut 12:18. Deuteronomy 14:26b echoes the language of Deut 12:17-18, which was also used in 14:23a, but gives these words a new addressee and the referent. The commands to eat and rejoice are now directed only to those who live far from the cult site- the more limited "you" who might avail themselves of the concession of Deut 14:24-26a, rather than to all Israelites. The meal that must be consumed "before YHWH" is now the substitute meal purchased with the proceeds of the firstling (or tithe) sale. Deuteronomy 14:26b uses the language and concepts of Deut 12:17-18 to claim that a meal arranged in accordance with the procedures outlined in the preceding verses fulfills the requirement to consume one's firstlings (and tithes) in a cultic meal.

\section{DEUTERONOMY 15:19-20: AN AMENDMENT TO DEUTERONOMY 12:17-18 AND 14:24-26}

Deuteronomy 15:19-20 amends both Deut 12:17-18 and Deut 14:24-26. Deuteronomy 15:19-20 rejects the concession of Deut 14:24-26 for the sale of firstlings, reasserting and justifying the demand of Deut 12:17-18 that firstlings be consumed in a cultic meal at the central sanctuary. Deuteronomy 15:19-20 is silent on the subject of tithes, and this silence amounts to a tacit acceptance of the concession of Deut 14:24-26 with respect to tithes. Comparison of Deut 14:24-26 and Deut 15:19-20 suggests that Deut 15:19-20 was written to amend Deut 14:24-26, partially rejecting it and hence partially restoring Deut 12:17-18.

The concession of Deut 14:24-26 does not mention tithes explicitly. Tithes and firstlings are explicitly listed in Deut 14:23, which reiterates the requirement to consume them in a cultic meal. In the concession itself, a pronominal suffix in v. 24 (שאתו "to convey it") and implied object in v. 25 (ונתתה "then you may sell [it]") point back to the tithes and firstlings listed in v. 23. Although context suggests that the concession applies to firstlings as well as tithes, the lack of any explicit references to firstlings in Deut 14:24 and 25 provided an interpretive opportunity for the author of Deut 15:19-20, which that author exploited. By characterizing firstlings in a way that makes their sale unthinkable, Deut 15:19-20 encouraged readers to reinterpret Deut 14:24-26 as if it only allowed the sale of tithes and not also firstlings. Deuteronomy 15:19-20 left no doubt about the immutable sacrality of every (ה) firstling, which was to be sanctified (קדש: v. 19) to the deity, could not be put to economic use (v. 19), and must be eaten before the deity (v. 20). As the history of interpretation shows, this strategy was largely successful.

Deuteronomy 15:19-20 addresses a consequence of firstling sale that is not mentioned in Deut 14:24-26: sold firstlings would be subjected to normal economic use. If a firstling were sold locally, the animal's new owner would face the same problem of distance, so it 
is unlikely that Deut 14:24-26 envisioned the new owner delivering the firstling to the sanctuary for a cultic meal. Instead, as argued above, the firstling's sacredness was transferred first to the money received for the sale and ultimately to the foods purchased for the substitute meal. All of this means that for its new owner, the firstling would effectively become a normal animal that could be eaten locally and used for economic purposes such as traction or wool. The command to set aside firstlings as sacred to the deity (v. 19) and the requirement of a cultic meal (v. 20) should preclude the sale of firstlings. As a failsafe, Deut 15:19-20 deprives firstlings of any potential economic value by prohibiting their economic exploitation for traction or wool (Deut 15:19), effectively eliminating any potential market for firstlings and undermining the concession allowing their sale. ${ }^{39}$ By commanding that all firstlings be set apart as sacred, prohibiting their economic use, and reiterating the command to consume them cultically, Deut 15:19-20 effectively removes firstlings from the concession of Deut 14:24-26 and limits the concession to tithes alone.

The foregoing observations suggest that Deut 15:19-20 was written to amend Deut 14:24-26, and it would be difficult to argue for dependence in the opposite direction, or that both texts stem from the same hand. Interpreters have consistently read Deut 15:1920 into Deut 14:24-26 for more than two millennia, which suggests that Deut 15:19-20 successfully amended Deut 14:24-26. The somewhat laconic presentation of Deut 14:24-26 would have been sufficient to circumvent the exclusion of firstlings from the local sphere Deut 12:17-18 but would have been inadequate to overpower the more explicit and forceful exclusion articulated in Deut 15:19-20.

Diachronic analysis of Deuteronomy's firstling regulations reveals a series of competent, effective, and successful amendments. The author of Deut 14:24-26 succeeded in amending Deut 12:1718 , and that success was later relativized by another successful amendment in Deut 15:19-20. Deuteronomy 12:17-18 and 15:19_ 20 are closely aligned in terms of legal substance, but they cannot be attributed to a single compositional layer because Deut 12:17-18 served as a source for Deut 14:24-26, whereas 15:19-20 responded to Deut 14:24-26.40 I conclude this article by considering the implications of this more complex compositional picture for our understanding of the legal hermeneutics of the Pentateuch and of relative and absolute dating of passages in Deuteronomy.

${ }^{39}$ Cf. Altmann's observation that "maintaining young domestic animals for the purpose of slaughter instead of for traction (plowing), wool, or milk constituted a significant economic burden" (Festive Meals, 74). Deuteronomy 15:19-20 makes no mention of milk because it deals specifically with male firstlings.

40 Otto, for example, argues for the literary unity of Deut 12:13-19; 15:19-23 (Deuteronomium: 12,1-23,15, 1369). 


\section{CONCLUSION: AMENDMENTS WITHIN DEUTERONOMY AND THE LEGAL HERMENEUTICS OF THE Pentateuch}

The complex processes of legal revision evident in the Pentateuch have been intensively examined, and the significance of these processes continue to be debated. A particularly important and enduring question is the basic purpose underlying legal revision: what relationship does a revising author intend for his new laws to have with those he has revised? Scholars remain divided on the intention behind Deuteronomy's rewriting of the Covenant Code: was Deuteronomy designed to replace the Covenant Code and stand independent of it, or to stand alongside it and supplement it in some way? Focusing on contradictions and tensions between the two corpora, many scholars have advocated a model of replacement. ${ }^{41}$ Others, emphasizing complementarities between Deuteronomy and The Covenant Code, regard Deuteronomy as a supplement. ${ }^{42}$ As I have argued elsewhere, both models have much to commend them, but neither provides a comprehensive picture of Deuteronomy's complicated relationship with the Covenant Code. ${ }^{43}$ A mediating model, which I have termed an "amendment model," better captures the full range of Deuteronomy's response, which includes contradictions and overriding as well as presupposition and complementation. ${ }^{44}$ These dynamics can be observed at the scale of individual laws and regulations. For example, Deuteronomy presupposes the Covenant Code's altar law as its starting point, echoing it and even referring to it even as it overrides the Covenant Code's distributed sacrificial cult with a centralized one. At larger scales, the Deuteronomic document presupposes and complements the Covenant Code, presenting itself not as a narration of the theophany and lawgiving at the divine mountain, but as a Mosaic recapitulation of these foundational events. This complementarity of setting is of crucial importance even if, as some

\footnotetext{
${ }^{41}$ Recent representatives of this position include Joel S. Baden, The Composition of the Pentateuch: Renewing the Documentary Hypothesis (AYBRL; New Haven: Yale University Press, 2012); Levinson, Deuteronomy and the Hermeneutics; and Stackert, Rewriting the Torah. For further discussion and bibliography see Mattison, Rewriting and Revision, 7-9.

42 Recent arguments for various supplementary positions can be found in Joshua A. Berman, "Supersessionist or Complementary? Reassessing the Nature of Legal Revision in the Pentateuchal Law Collections," JBL 135 (2016), 201-22; Hindy Najman, Seconding Sinai: The Development of Mosaic Discourse in Second Temple Judaism (Supplements to the Journal for the Study of Judaism, 77; Leiden: Brill, 2003); Otto, "Hermeneutics of Deuteronomy"; Konrad Schmid, "Deuteronomy within the 'Deuteronomistic Histories' in Genesis-2 Kings," in Konrad Schmid and Raymond F. Person, Jr. (eds.), Deuteronomy in the Pentateuch, Hexateuch, and the Deuteronomistic History (FAT, 2.56; Tübingen: Mohr Siebeck, 2012), 8-30. For further discussion and bibliography see Mattison, Rewriting and Revision, 9-14.

43 Mattison, Rewriting and Revision, 7-14.

${ }^{4}$ Ibid., 14-27.
} 
scholars suspect, these settings are secondary, because it shows a continuity between earlier and later layers of Deuteronomy, all of which presuppose and complement the Covenant Code and the narratives that frame it. Throughout its evidently long and winding history of composition, Deuteronomy's authors continued to respond to the Covenant Code. The one group that we can safely say read Deuteronomy - its subsequent editors - seems to have read it alongside the Covenant Code and understood that their role was not to replace or eliminate the Covenant Code but to read new meanings into it. 45

As generations of scribes continued to develop the text of Deuteronomy to respond to perceived deficiencies in the Covenant Code, they also responded to shortcomings they saw in their own text. This sort of internal revision is reflected in Deuteronomy's succession of firstling regulations. Each secondary author presupposes the existing firstling regulations, complements them by filling in any gaps, and overrides them at points of disagreement. Deuteronomy 14:24-26 was designed to alter the reader's understanding of Deut 12:17-18, and Deut 15:19-20 corrected a perceived error in Deut 14:24-26. Secondary authors did not merely compose new texts that contradicted existing ones. They composed new texts that dictated the terms on which existing texts would be read. Similar amending methods are evident, for example, in Deuteronomy's law of cultic place and sacrifice (Deut 12:1-28). An initial law establishes that all sacrifice must take place at the deity's one chosen site, whereas nonsacrificial slaughter is permitted elsewhere (see vv. 13-19). Later amendments limit local slaughter only to places far from the cult site (v. 21), delay centralization (vv. 8-12), and delay local slaughter to synchronize it with the onset of centralization (v. 20). The initial formulation of the law and its several amendments continue to respond to the Covenant Code's altar law as well. ${ }^{46}$

The methods for internal amendment within Deuteronomy can help us better understand Deuteronomy's interactions with external source texts such as the Covenant Code. The strategies employed in inner-Deuteronomic revision bear significant similarities to the methods used in Deuteronomy's reworkings of the Covenant Code. Deuteronomy 14:24-26 is bracketed with citations of Deut 12:1718 that change the cited text's meaning: the quotation in Deut 14:23 introduces an exception not anticipated by Deut 12:17-18, and the quotation in $\mathrm{v} .26$ equates the substitute cultic meal with the firstling (or tithe) meal that Deut 12:17-18 required. Deuteronomy similarly employs tactics of echoing and citation at key points of disagreement to impose new meanings on the Covenant Code. An especially close parallel to Deut 14:26b is Deut 16:16-17, which quotes the Covenant

\footnotetext{
45 Ibid., 178.

46 On this series of amendments and their relationships to existing Deuteronomic texts and to the Covenant Code, see Levinson, Deuteronomy and the Hermeneutics, 23-52; Mattison, Rewriting and Revision, 29-86.
} 
Code so as to present the radical revision of the Covenant Code's festival calendar in the foregoing verses (Deut 16:1-15) as equivalent to that calendar. ${ }^{47}$ Deuteronomy 15:19-20 rejects the allowance of firstling sale, without ever acknowledging its existence, through a series of positive requirements that preclude the possibility. This method parallels Deuteronomy's "silent polemics" against pre-existing texts and institutions. ${ }^{48}$

The chronological development of Deuteronomy's firstling legislation also reflects an increasing affinity with Priestly and Holiness ideas and perhaps an increasing awareness of Priestly and Holiness texts or an increasing willingness to interact with them. Deuteronomy 15:19-20 effectively brings Deuteronomy's tithe and firstling legislation into closer alignment with the Priestly/Holiness view that vegetable tithes can be redeemed (Lev 27:30-31) but sacrificable animal firstlings cannot (Num 18:17). Deuteronomy 15:19-20 still diverges substantially from Priestly/Holiness views, however, in allowing lay Israelites to consume their own firstlings rather than giving them to the Priests (Num 18:17-18). Several scholars see a further substantive contradiction between Deuteronomy's command and the Priestly prohibition לא יקדיש איש אדיש "one may not dedicate a firstling" (Lev 27:26).49 Rather than contradicting one another, these passages use different meanings of קדש. Lev 27:26 uses קדש to refer to the transfer of an object from the secular to the sacred sphere, whereas Deuteronomy 15:19 refers to the separation of something that is intrinsically sacred. .00 A firstling can be "set apart" because it is born into the owner's flock (Deut 15:19), but it cannot be "sanctified" because it is intrinsically sacred (Lev 27:26).

This apparent awareness of Priestly/Holiness viewpoints allows us to place Deuteronomy's internal development in the context of the Pentateuch's overall composition and gets us closer to a possibility of absolute dating. First of all, the affinities of Deut 15:19-20 with Priestly thought support this paper's conclusion, based on inner-Deuteronomic evidence, that Deut 15:19-20 is relatively late. Second, Deut 15:19-20 does not apparently attempt to harmonize Deuteronomy with priestly concepts or texts, but instead utilizes priestly ideas to improve Deuteronomy itself. Thus, Deut 15:19-20 is "Deuteronomic" (or Deuteronomistic) rather than "pentateuchal" in its outlook. ${ }^{51}$

${ }^{47}$ Levinson, Deuteronomy and the Hermeneutics, 90-93.

48 See, for example, ibid., 125.

49 Milgrom, Leviticus 23-27, 2388; Weinfeld, Deuteronomy and the Deuteronomic School, 215.

${ }^{50}$ See Gershon Brin, "Problems Concerning the First-Born of Human Beings," in Studies in Biblical Law: From the Hebrew Bible to the Dead Sea Scrolls, trans. Jonathan Chipman (JSOTSup, 176; Sheffield: JSOT Press, 1994), 209-37, 218; Morrow, Scribing the Center, 122-24; Nielsen, Deuteronomium, 165.

51 A similar phenomenon may be present in Deut 19:8-10, which prescribes a second wave of three asylum cities, bringing Deuteronomy up to 
Proposing absolute dates for such a small sliver of texts is precarious. Rather than speculate on the basis of only a few verses, I will comment very briefly on how the observations made here can build on existing models for the book of Deuteronomy and how further refinements might be made. Eckart Otto's monumental commentary and related works on Deuteronomy reflect the state of the art in reconstructing Deuteronomy's composition history and its place within the Pentateuch. ${ }^{52}$ Otto assigns the three main passages treated in this study to Deuteronomy's original composition and hence to seventh-century Judah. I agree with this ascription in the case of Deut 12:17-18: many scholars have rightly found in Deut 12:13-19 Deuteronomy's original response to the Covenant Code's altar law. I would also agree that both Deut 14:23-26 (And 14:2229 as a whole) and 15:19-20 (and 15:19-23 as a whole) have the Covenant Code in view. But in light of the evolution of thought retraced in this study, I would suggest that these passages derive primarily from developments within Deuteronomy, and I would therefore be inclined to push their composition to later periods. If this is correct, Deut 14:22-29 and 15:19-23 would be examples of the phenomenon proposed above: not only Urdenteronomium, but each successive edition of Deuteronomy, continues to respond to the Covenant Code. I would also link the invocation of distance in Deut 14:24 to the similar formulation of Deut 12:21 and see this as a formula for justifying amendments within Deuteronomy. The somewhat different invocation of distance in Deut 19:6 also reflects similar thinking and may reflect a similar compositional context. The explicit invocations of the problem of distance in Deut 12:21; 14:24; 19:6 reflect on the fallout of centralization. They do not necessarily reflect the practice of centralization but they are eminently practical in their outlook. I would therefore suggest that these amendments stem from a very early revision of Deuteronomy in pre-Exilic Judah. Later amendments use different introductory formulae that refer to territorial expansion (Deut 12:20; 19:8) or even initial conquest and settlement (Deut 7:1; 17:14). While all of these formulae may simply reflect Deuteronomy's narrative context rather than the historical circumstances of its authors, it is notable that the references to distance are more amenable than the other formulas to enforcement of Deuteronomy in the present rather than the future, and in fact the invocations of distance do not require a Mosaic setting. If, as I have argued, Deut 15:19-20 reflects a still later development, the exilic period would fit the passage's stricter, more idealistic outlook as well

par with the Priestly/Holiness text of Num 35:9-34 but not harmonizing the texts: see Mattison, Rewriting and Revision, 171-73.

${ }^{52}$ Eckart Otto, Deuteronomium 1-11: Erster Teilband 1,1-4,43 (HThKAT; Freiburg: Herder, 2012); Eckart Otto, Deuteronomium 1-11: Zweiter Teilband 4,44-11,32 (HThKAT; Freiburg: Herder, 2012); Otto, Deuteronomium 12,123,15; Eckart Otto, Deuteronomium 12-34: Zweiter Teilband 23,16-34,12 (HThKAT, 4b; Freiburg: Herder, 2017). 
as its affinities with Priestly literature. A date in the early Persian period is also possible, but again I would stress that Deut 15:19-20 seems to aim at improving Deuteronomy based on Priestly ideas rather than integrating Deuteronomy with Priestly texts into a Pentateuch or Hexateuch.

The preservation of multiple viewpoints within Deuteronomy can help us better understand Deuteronomy's place in the larger picture of Pentateuchal composition and compilation. Deuteronomy's authors preserved multiple views in their own text, and they may also have "accommodated" external texts such as the Covenant Code, despite points of serious disagreement. Deuteronomy's firstling legislation represents just one of many cases in which minor issues of internal composition history can shed light on larger issues of composition, interpretation, and their intersection. 